\title{
HÜTŐKÖZEG VÁLTÁS HŐSZIVATTYÚRA GYAKOROLT HATÁSÁNAK MÉRÉSI LEHETŐSÉGEI
}

\author{
Hermanucz Péter - Géczi Gábor - Barótfi István
}

\begin{abstract}
Absztrakt: A hőszivattyúkban alkalmazott hütőközegek többsége jelentősen hozzájárul a globális felmelegedéshez, ezért az utóbbi időben korlátozzák a felhasználható mennyiséget. E korlátozások ösztönzik az úgynevezett természetes hütőközegek alkalmazását, melyek környezetkárosító hatása minimális. Használatuk új hőszivattyú konstrukciók esetén nem okoz problémát, azonban olyan gépek esetében, melyek müszaki állapota lehetőv é teszi a további üzemelést, nem rendelkezünk kellő ismeretekkel a hütőközeg váltás berendezésre gyakorolt hatásairól. Jelen munkában be kívánjuk mutatni azon mérési lehetőségeket, melyek egy hütőközeg váltás hatásainak vizsgálatát teszik lehetővé egy kísérleti berendezésen.
\end{abstract}

\begin{abstract}
The majority of refrigerants used in heat pumps make a significant contribution to global warming and have recently been limited in their use. These restrictions encourage the use of so-called natural refrigerants with a minimal environmental impact. Their use in the case of new heat pump constructions is not problem, however, in the case of machines whose technical condition allows further operation, we do not have sufficient knowledge of the effects of refrigerant change on the equipment. In this work, we would like to present the measurement options that allow the investigation of the effects of a refrigerant change on an experimental device.
\end{abstract}

Kulcsszavak: természetes hütőközeg, höszivattyú, TEWI, HFC

Keywords: natural refrigerants, heat pump, TEWI, HFC

\section{Bevezetés}

Az alkalmazott hütőközeg - mely alapvetően meghatározza a hőszivattyú élete során okozott környezetterhelés mértékét (Hermanucz et. al. 2018) - káros hatásának visszaszorítására és különféle jogszabályokat léptettek életbe. Ezen előírások behatárolják bizonyos hütőközegek alkalmazásának lehetőségeit pro és kontra: A fokozott környezeti kockázatot jelentő HFC-típusú hütőközegeket pl. fokozatosan kiszorítják. Másokat korlátozásokkal ugyan, de elötérbe helyeznek: ilyenek az úgynevezett természetes hütőközegek, melyek közül több rendelkezik közvetlen egészségügyi kockázattal, például mérgező hatással, vagy közvetett hatással, például tüz- és robbanásveszélyes. (Harby, 2017) Ezen felül a jelenleg üzemelö berendezésekre gyakorolt hatásukról nem rendelkezünk elegendő információval, így e terület vizsgálata indokolt, ugyanakkor bizonyos mérési nehézségek merülhetnek föl.

Célunk azoknak a jellemzőknek és a mérésükhöz szükséges átalakítások bemutatása, melyek segítenek megismerni az egyes hütőközegek hütőkörre gyakorolt hatását energetikai szempontból. Ahol pedig a mérés túlságosan bonyolítaná az eljárást, ott megoldást mutatok a vizsgált jellemző számítással történő meghatározására. Tekintve, hogy jelenleg nem áll rendelkezésre széles körben alkalmazott, szabványosított mérőberendezés hütőközegek valós körülmények között történő vizsgálatára, a kutatás fontos részét képezi egy erre a célra alkalmas berendezés kialakítása, mely munkának jelenleg az elején járunk. 


\section{Anyag és módszer}

Munkánk során egy egyedi építésü, ám számos átalakítást igénylő és dokumentációval nem rendelkező berendezést fejlesztettuink tovább úgy, hogy az alábbi elvárásoknak megfeleljen:

- A kondenzátor oldal egy hütőközeg-víz hőcserélö legyen

- Rendelkezzen egy levegős és egy vizes elpárologtatóval

- A vizes elpárologtató és a kondenzátor vízoldali teljesítménye mérhető

- A kompresszor felvett hatásos villamos teljesítménye mérhető

- A kompresszor szívó- és nyomó oldalán a hőmérsékletek és nyomások mérhetőek

- A hőcserélők hűtőközeg be-és kilépő oldalán a hőmérséklet és a nyomás mérhető

- A hütőközeg cseréje egyszerüen kivitelezhető

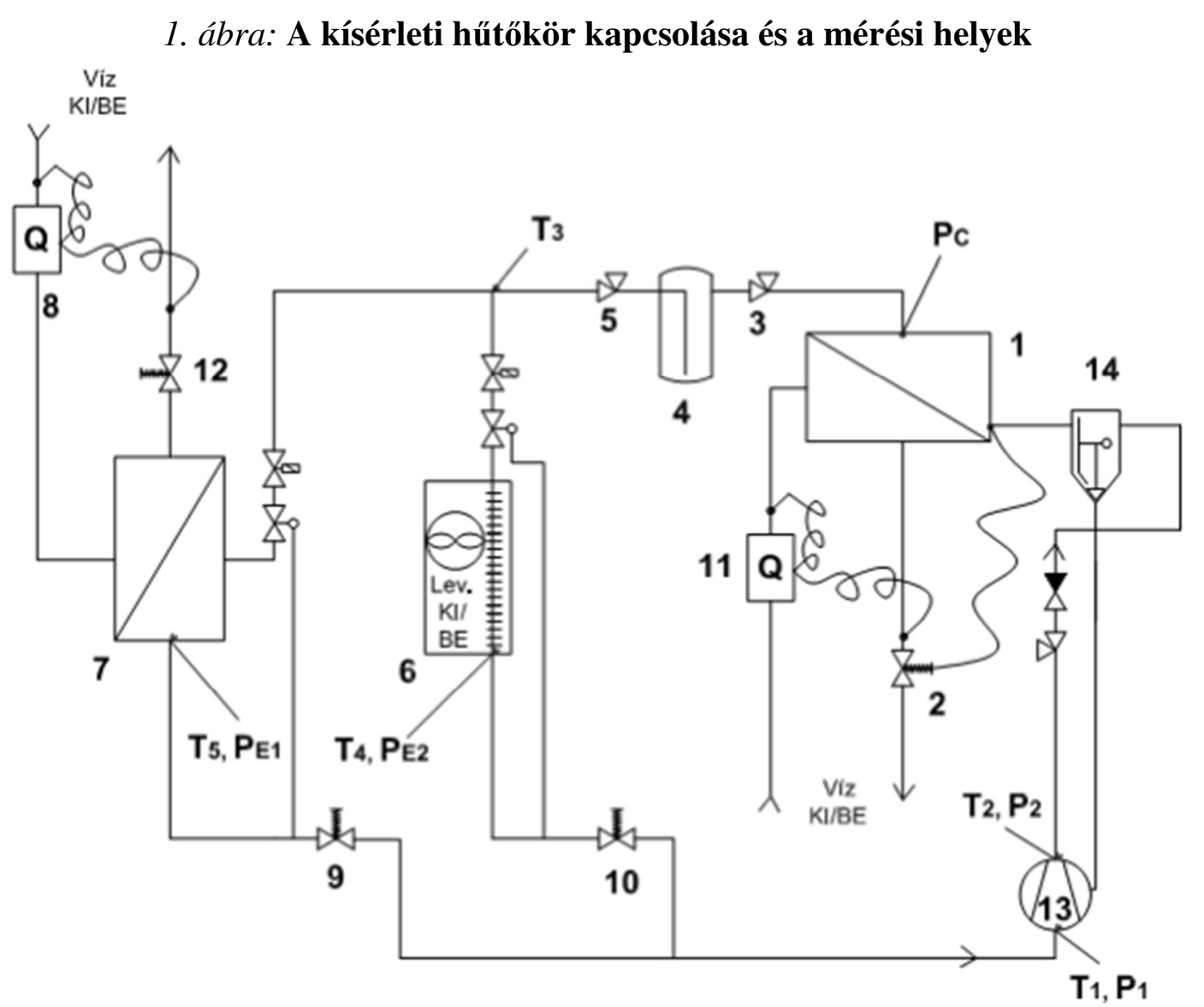

Forrás: A szerző saját szerkesztése.

1-egyedi építésü, koaxiális kondenzátor, 2-kondenzációs nyomás szabályzó, 3/5-sarokszelep, 4-folyadékgyüjtő, 6-levegő hőforrással rendelkező elpárologtató, 7-víz hőforrással rendelkező elpárologtató, 8-elpárologtató oldali hőmennyiségmérő, 9/10-elpárolgási nyomásszabályzó, 11- kondenzátor oldali hőmennyiségmérő, 12-vízmennyiség szabályzó szelep, 13-kompresszor, 


\section{Eredmények és értékelésük}

A kutatás jelen fázisában nem rendelkezünk több hütőközegre vonatkozó, összehasonlítható mérési adatsorokkal. Jelenleg a munka elején járunk, így egy adott hütőközeggel (R404a-val) végeztünk próbaméréseket. Az alábbiakban így csak kevés mérési eredmény bemutatására lesz lehetőségünk, inkább a kísérleti berendezés átalakítása során végzett beavatkozásokat ismertetjük.

\subsection{Speciális kondenzátor építése}

A kondenzátor úgy került kialakításra, hogy alkalmas legyen mérési célokra, ennek megfelelően rendelkezik hütőközeg oldali nyomásmérési pontokkal, mely a kereskedelemben kapható típusoknál nem áll rendelkezésre. A beépített kondenzációs nyomásszabályzó is e pontra csatlakozik, így alkalmas a kondenzációs nyomás pontos értékének beállítására és stabilan tartására. (Jakab, 2006) A hőcserélő vízoldali térfogatát minimalizáltam, ezért egy-egy beállítás alkalmával kis idő elteltével már stabil kondenzációs nyomással dolgozik a berendezés. Ezt a próbamérések során sikerült igazolni, a stacioner kondenzációs nyomás eléréséhez mindössze $40 . .660$ másodpercre volt szükség, és az értékeket lengés nélkül sikerült tartani. A hőmennyiség mérési eredmények ugyanakkor jóval hosszabb várakozási időt tesznek szükségessé, ezt szemlélteti a 2. ábra.

\subsection{Hőmennyiség mérés kialakítása}

A kondenzátor és a vizes elpárologtató által forgalmazott hőmennyiséget vízoldalon tettem mérhetővé hőmennyiség mérők segítségével. A müszerek stabilitása, pontossága, de különösen felbontó képessége alkalmassá teszi őket pontos mérések elvégzésére. A feladat szempontjából igen fontos pillanatnyi teljesítmény értékek $0,001 \mathrm{~kW}$ felbontással olvashatók le $20 \mathrm{~s}$-os időközönként. E tulajdonságukat kihasználva a próbamérések során sikerült meghatározni a rendszer beállásához szükséges időt, mely hozzávetőleg 600 s-ra adódott. 


\section{1. ábra: Hőmennyiség mérési eredmények egy adott üzemállapotban}

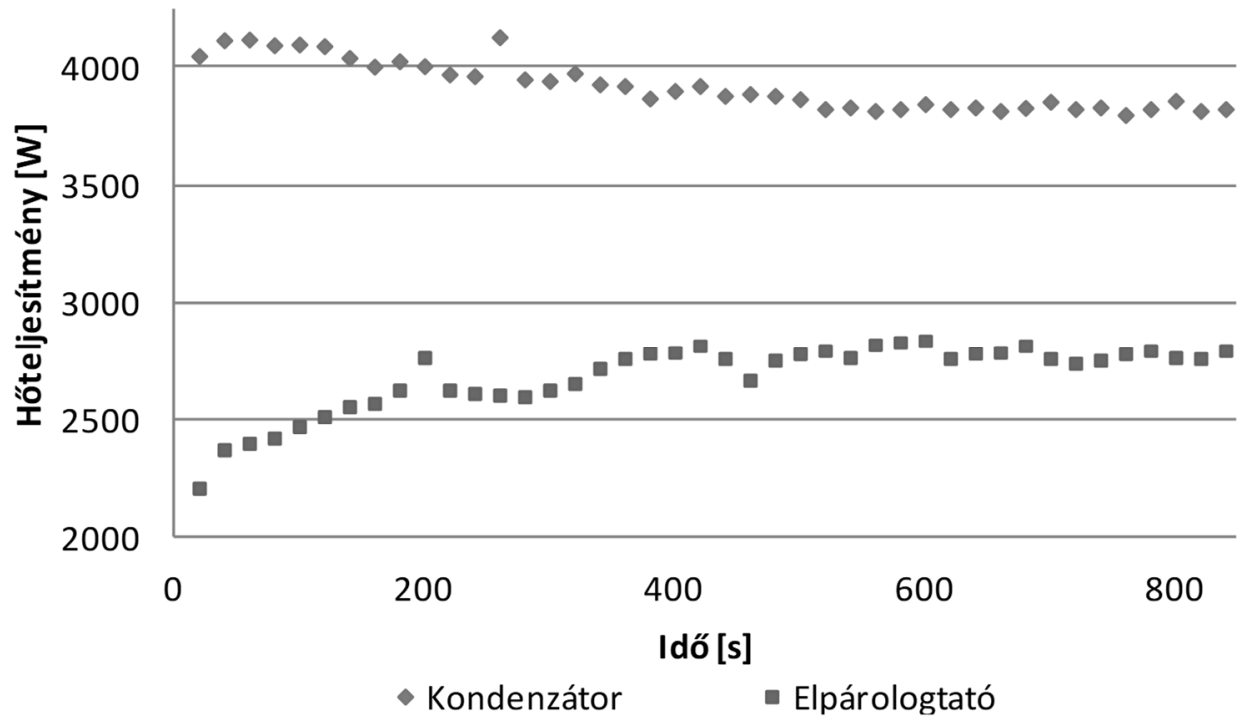

\subsection{A hö- és nyomásmérési helyek feltárása és átalakítása}

A berendezés alapvetően szemléltetési célokat szolgált, ezért annak ellenére, hogy számtalan mérési helyet alakítottak ki rajta, néhányat meg kellett változtatni. Ez elsősorban a $\mathrm{T}_{5}$ és $\mathrm{T}_{6}$ hőmérsékletek mérését jelenti. A problémát két meglevő hőérzékelö újra vezetékezésével oldottam meg, így a többivel megegyező szondával és müszerrel történhet a mérés e két helyen is, lásd l. táblázat.

\section{1. táblázat: A méréshez használt müszerek}

\begin{tabular}{cccc}
\hline Mért jellemző & Jelölés & Alkalmazott műszer & Mérési pontosság \\
\hline Nyomás & $\mathrm{P}_{1}, \mathrm{P}_{3}$ & Dixell XC440c Honeywell távadóval & $+/$ - $1 \%$ \\
& $\mathrm{P}_{\mathrm{E} 1}, \mathrm{P}_{\mathrm{E} 2}, \mathrm{P}_{2}$ & Refco analóg nyomásmérő & 1-es osztálypontosság \\
Hőmérséklet & $\mathrm{T}_{1}, \mathrm{~T}_{2}, \mathrm{~T}_{3}, \mathrm{~T}_{5}, \mathrm{~T}_{6}$ & Dixell XR01cx PTC érzékelővel & $+/-0,7^{\circ} \mathrm{C}$ \\
Villamos telj. & $\mathrm{W}_{\mathrm{KOMP}}$ & Everflourish EMT 707CTL & $+/$ - $1 \%$ \\
Hómennyiség & $\dot{Q}_{k} \dot{Q}_{E 2}$ & Techem Compact $\mathrm{V}$ e. Hómennyiségmérő & Mérés: $\mathrm{DT}=0,2 \mathrm{~K}$-től \\
\hline
\end{tabular}

\subsection{Nehezen mérhető jellemzők}

A levegő hőforrásból fölvett teljesítmény mérése nehézségekbe ütközik: az elpárologtató homlokfelületén több pontban kellene légsebességet- és hőmérsékletet mérni, számítani a levegő sürüségét, sok mérési pontot kiértékelni egy üzemállapotban. A levegőből kondenzálódó nedvesség hatását is igen nehéz lenne figyelembe venni. Ez jelentősen bonyolítaná a mérést és bizonytalanságot is vinne bele, ezért a levegő hőforrásból fölvett teljesítményt számítással határozzuk meg. A számítások elvégzéséhez elengedhetetlen a kondenzátorban leadott hőmennyiség, továbbá a be- és kilépő oldalon a hütőközeg entalpiájának pontos ismerete. Ehhez 
$\mathrm{T}_{2}, \mathrm{~T}_{3}$, és $\mathrm{P}_{\mathrm{k}}$ értékeire van szükség, majd a $\log \mathrm{P}-\mathrm{h}$ diagram ill. szoftver segítségével az entalpia értékek meghatározhatók. Erre a célra a Solvay Fluor cég „Solkane 7.0” adatbázisát használjuk. A levegő hőhordozóból fölvett teljesítmény számításához először a hőcserélőbe juttatott $\dot{m}_{R 2}$ hütőközeg tömegáramot kell meghatározni:

$$
\dot{m}_{R 2}=\dot{m}_{R}-\dot{m}_{R 1}[\mathrm{~kg} / \mathrm{h}]
$$

ahol:

$$
\begin{gathered}
\dot{m}_{R}=\frac{\dot{Q_{K}}}{h_{2}-h_{3}} \quad[\mathrm{~kg} / \mathrm{s}] \\
\dot{m}_{R 1}=\frac{\dot{Q_{E 1}}}{\left(h_{5}-h_{3}\right)} \quad[\mathrm{kg} / \mathrm{s}]
\end{gathered}
$$

$\mathrm{h}_{2}, \mathrm{~h}_{3}, \mathrm{~h}_{5}$ a mért nyomások és hőmérsékletek alapján a szoftver segítségével pontosan meghatározható, $\dot{Q}_{K}$ és $\dot{Q}_{E 1}$ pedig a hőmennyiség mérésből ismert, így a levegős elpárologtatóba jutott hütőközeg tömegáram számítható, melyből az elpárologtatóban fölvett teljesítmény meghatározható:

$$
\dot{Q}_{E 2}=\dot{m}_{R 2} \cdot\left(h_{6}-h_{3}\right)[\mathrm{kW}]
$$

\section{3.ábra: A körfolyamat és a mérési pontok a logP-h diagramban}

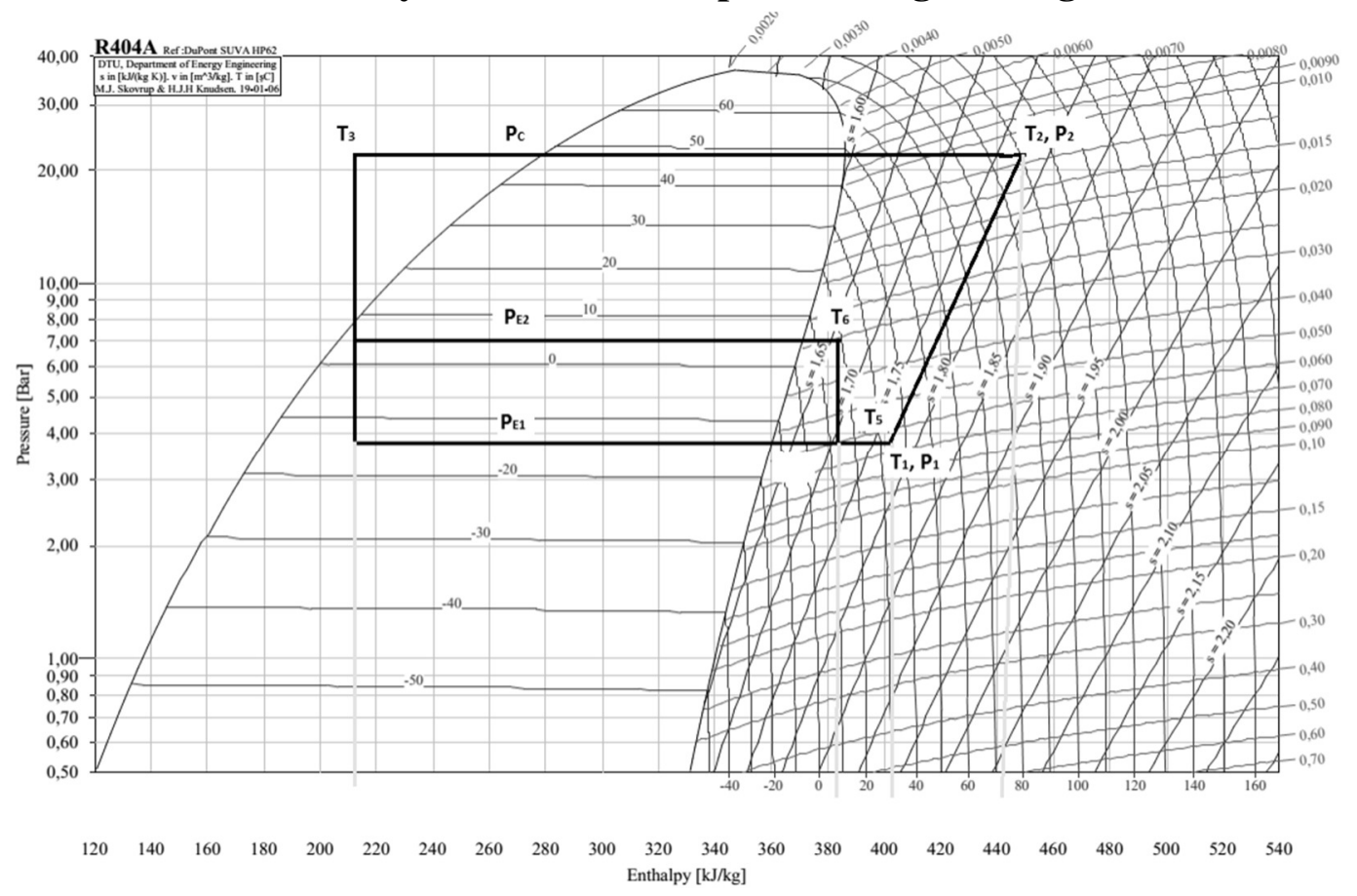

Forrás: A szerző saját szerkesztése.

A jobb olvashatóságért az ábrán minimális elhanyagolásokkal éltem (Jakab, 2006). A mért jellemzők jelölése megegyezik a kapcsolási vázlaton alkalmazottakkal. 


\section{4. Összegzés}

A hütőközeg váltás legfontosabb vizsgálati paramétere a körfolyamatot jellemző pontokon mért nyomás- és hőmérséklet értékek mellett végeredményben a teljesítménytényező. (COP - Coefficient Of Performance) Vizsgálataink során az egyszerủen meghatározható „összehasonlíthatô” teljesítmény tényezőt (Jakab, 2006.) vettük alapul a számításhoz:

$$
\mathrm{COP}=\frac{h_{2}-h_{3}}{h_{2}-h_{1}}[-]
$$

Így a gyakorlatban megszokottnál magasabb, esetünkben pl. 6,5..6,8 közötti értékek adódnak, szemben a valós, minden veszteséget figyelembe vevő számítási móddal, ahol 3,5...3,8 közé adódik a teljesítménytényező értéke. Ennek ellenére elönyösnek tartjuk az (5) szerinti számítási módot, hiszen a kompresszor típusától, belső hatásfokától, hajtási módjától függetleníti az eredményeket, tehát akár teljesen más kompresszorral megvalósított körfolyamattal is összehasonlíthatóak lesznek az eredmények, így az eltérő hütőközegek vizsgálatát is megkönnyíti (Makhnatcha, 2014).

Az átalakított kísérleti berendezés a próbamérések tanúsága szerint alkalmas azon energetikai jellemzők mérésére, beállítására és reprodukálására, melyek segítségével különféle hütőközegek hőszivattyú körfolyamatára gyakorolt termodinamikai hatásai mérhetőek. Az alkalmazott két elpárologtatós kapcsolás lehetővé teszi két hőforrás önálló, vagy akár párhuzamos hasznosítását. Ezzel a megoldással akár optimalizálni is lehet a körfolyamatot bizonyos hütőközegek alkalmazásához.

\section{Irodalomjegyzék}

Harby K. (2017): Hydrocarbons and their mixtures as alternatives to environmental unfriendly halogenated refrigerants: An updated overview, Renewable and Sustainable Energy Reviews, Vol.7: 1247-1264

Hermanucz P., Barótfi I., Géczi G. (2018): Höszivattyúk alkalmazásának környezetvédelmi aspektusai, Környezet és energia, Debrecen ISBN 978-963-7064-36-4:

Jakab Zoltán, 2006, Kompresszoros hütés, HKVSZ Kiadó, Budapest:

EU Regulation No. 517/2014 Annex V.

Makhnatcha P., Khodabandeha R. (2014): The role of environmental metrics (GWP, TEWI, LCCP) in the selection of low GWP refrigerant, Energy Procedia, Vol. 61: 2460-2463 